\title{
Genetic diversity of Asian water buffalo (Bubalus bubalis): mitochondrial DNA D-loop and cytochrome $b$ sequence variation
}

\begin{abstract}
Swamp and river buffalo mitochondrial DNA (mtDNA) was sequenced for 303 bp of the cytochrome b gene for 54 animals from 14 populations, and for 158 bp of the D-loop region for 80 animals from 11 populations. Only one cytochrome b haplotype was found in river buffalo. Of the four haplotypes identified in swamp buffalo, one found in all populations is apparently ancestral both to the other swamp haplotypes and to the river haplotype. The phylogenetic relationships among the 33 D-loop haplotypes, with a cluster of 11 found in swamp buffalo only, also support the evolution of domesticated swamp and river buffalo from an ancestral swamp-like animal, most likely represented today by the wild Asian buffalo (Bubalus arnee). The time of divergence of the swamp and river types, estimated from the Dloop data, is 28000 to 87000 years ago. We hypothesise that the species originated in mainland south-east Asia, and that it spread north to China and west to the Indian subcontinent, where the rive type evolved and was domesticated. Following domestication in China, the domesticated swamp buffalo spread through two separate routes, through Taiwan and the Philippines to the eastern islands of Borneo and Sulawesi, and south through mainland southeast Asia and then to the western islands of Indonesia.
\end{abstract}

Keyword: Bubalus bulabis; Buffalo evolution; Control region; Cytochrome b; D-loop; Genetic diversity; Mitochondrial DNA 